\title{
Educational Platform SOLL with the IoT
}

\author{
Andreia Magalhães ${ }^{1 *}$, António Andrade ${ }^{2}$, José Matias Alves ${ }^{3}$ \\ ${ }^{1}$ Centro de Investigação em Desenvolvimento Humano, Universidade Católica Portuguesa, Porto, PORTUGAL \\ ${ }^{2}$ Centro de Estudos em Gestão e Economia, Universidade Católica Portuguesa, Porto, PORTUGAL \\ ${ }^{3}$ Centro de Investigação em Desenvolvimento Humano, Universidade Católica Portuguesa, Porto, PORTUGAL
}

*Corresponding Author: andreiamagalhaes78@gmail.com

Citation: Magalhães, A., Andrade, A. and Alves, J. M. (2019). Educational Platform SOLL with the IoT. Journal of Information Systems Engineering \& Management, 4(4), em0101. https:/ / doi.org/10.29333/jisem/6345

Published: December 7, 2019

\begin{abstract}
The Internet of Things (IoT) is a network composed of various objects and devices connected to the Internet, which emerge with great potential for education.

Thus, in order to verify the potential of IoT in an interdisciplinary approach of the science curriculum in the 3rd Cycle of Basic Education emerges project SOLL: Intelligent Objects Linked to Learning, which is an interactive, dynamic and interdisciplinary learning platform, supported by a set of technologies that collect and store data from a greenhouse for later interdisciplinary analysis.

In this article, the platform's architecture is exposed and, from a mixed methodology - student questionnaires, teacher focus group interviews and continuous observation of participants recorded in the researcher's diary - the data obtained show that this platform respond to the new learning community structure, by adopting a different learning model, with exploration of interests and enrichment of educational experiences.
\end{abstract}

Keywords: education, technology, Internet of Things

\section{INTRODUCTION}

"Technologies are in society and bring new challenges, needs and possibilities" (Bruno et al., 2019: 62). In other words, "they provide many opportunities, but also many risks, for a society that is poorly prepared for the challenges of a rapidly changing world" (Patrício, 2019: 34). since, the same author adds, "young people constantly need digital and media literacy and knowledge to engage more critically, competently, confidently and responsibly in the digital environment" (Patrício, 2019: 34), offering "young people additional tools for the search of information and knowledge "( Morgado, 2015: 167).

Similarly, the European Commission (Comissão Europeia, 2012) states that "digital technologies have an impact on education, training and learning through the development of more flexible learning environments adapted to the needs of a highly mobile society".

In this context, given the explosion of knowledge that has taken place, the teaching model cannot continue to be guided by the transmission of knowledge. This will have to evolve into a model based on the "cultivation of skills," (Adrião, 2018: 98) in which the student needs a more active role, given the high speed of information and knowledge spread in today's society, students will have to maintain lifelong learning, and it is necessary that they be equipped with tools that allow them to evaluate and assimilate new knowledge. 
In this context, the teaching-learning process is understood as a construction that involves an active role on the part of the students. It is imperative that they develop the capacity to establish their own goals, to plan and monitor their efforts towards a better academic performance, directing to a certain extent, their learning in the school context (Souza, 2010). According to Adrião (2018: 134), the interactivity provided by the digital educational resources can help both in the task of teaching and in the task of learn.

According to Osborne and Dillon (2008) for technologies to translate into effective improvement of learning, the teacher must ensure that the use of technology is appropriate and values the learning in question; the use of the technologies must be framed in the current pedagogical practices of the teacher and in the preconceptions of the students; the activity should be structured so that the students have to assume some responsibility and have the opportunity to develop an active participation; it is essential to promote in students the reflection on the underlying concepts and relationships, creating moments of discussion, analysis and reflection; the focus should be on the research activity by developing skills in data collection and analysis; should clarify the relationship between the use of technologies and the process of teaching and learning in progress; sharing of findings and ideas within the class group should be encouraged. The use of new technologies, according to Reid-Martinez and Grooms (2018), actively encourage and support constructivist pedagogy that, in this way, is more likely to reach all students who wish to participate in the process of knowledge construction and teachers who implement it have further improved technology environments (Sultan et al., 2011). Predicting that the result could be a democratization of education not previously seen (Reid-Martinez and Grooms, 2018) and an aid in the fight against school failure.

For this reason, the Internet of Things introduced "a novel paradigm that is rapidly gaining ground in the modern wireless telecommunications scenario" (Atzori et al., 2010). Some authors argue that it is an unprecedented technology (Kranenburg et al., 2016). Is such an innovative technology that its impact on society will be equivalent to that of an Industrial Revolution (O'Brien, 2016).

The classic Atzory et al. (2010) states that:

"The basic idea of this concept is the pervasive presence around us of a variety of things or objects - such as Radio-Frequency IDentification (RFID) tags, sensors, actuators, mobile phones, etc. - which, through unique addressing schemes, are able to interact with each other and cooperate with their neighbors to reach common goals."

Xia, Yang, Wang, and Vinel (2012) refer to the Internet of Things as a network interconnection of everyday objects, which are often equipped with ubiquitous intelligence. They also add that this technology will increase the ubiquity of the Internet because it will integrate all objects into an embedded system, which will give rise to a strongly present network of objects communicating with humans or other objects. In the same sense, Singer (2012) defines IoT as a worldwide network of connected objects, which exchange ample information between them. For Gubbi et al. (2013), IoT is considered as something more user-centered and not restricted to communication protocols, that is, it is the

\footnotetext{
"Interconnection of detection and actuation devices, providing the ability to share information across platforms through a unified framework, developing a common operational framework to enable innovative applications. This is achieved by ubiquitous detection, data analysis, and information representation with cloud computing as a unifying structure" (Gubbi et al., 2013: 1647).
}

In other words, it is a technology that allows, through sensors, to connect objects with the Internet so that information about the environment or activity can be obtained and that will provide feedback and control (O'Brien, 2016).

Given that it is recognized that the teaching model cannot continue to be based on the transmission of knowledge, the Internet of Things presents itself as an added value, since, according to Aldowah et al. (2017) "new forms of information exchange lay the foundation for more interactive and personalized learning" and real-time data "are useful for analyzing actions, interactions, preference trends and changes in student skill levels" (Aldowah et al., 2017). The teacher remains "essential for guiding students to and through learning objects" and "must also take students away from the variety of disconnected experiences to develop meaning and assimilate their new knowledge, skills and emotions" (Slimp and Bartels, 2019: 35).

In this sense, the Internet of Things is a technology that is useful for students to explore real-world situations in order to "build their own knowledge" (Costa, 2014: 116) through the collection of real-time data, issued by these connected environments (Johnson et al., 2015). Presents itself as a technology with interest for application in Education because, with it, students will have the ability to monitor their own surrounding environment and collect 
data in real time for future study, with data emitted by these connected environments (Johnson et al., 2015), allowing the exploration of subjects that meet the interests and context of students and their community.

In order to operationalize the above, the SOLL platform: Smart Objects Linked to Learning emerged, which is supported by a set of technologies that collect and store real data for later interdisciplinary analysis.

\section{SOLL PROJECT: SMART OBJECTS LINKED TO LEARNING}

In order to take advantage of technology to create for students special learning conditions "so that, throughout their lives, they are able to critically select and seek the knowledge they wish to acquire, and integrate them into the set of knowledge that they already have and are capable of conducting a practice based on them " (Costa, 2014: 69), the SOLL: Smart Objects Linked to Learning (Magalhães et al., 2019) project was created:, which is based on the construction of a greenhouse, monitored by sensors that, through the Internet of Things, transmit real data in real time and constantly updated for the SOLL platform. From this, the students perform a set of activities, which fulfill the Essential Learning of the subjects of the 3rd Cycle of Basic Education, and intervene on the environment, acquiring new values. From the interaction between the different project targets, as shown in Figure 1, all the work is developed by students in an integrated and interdisciplinary way.

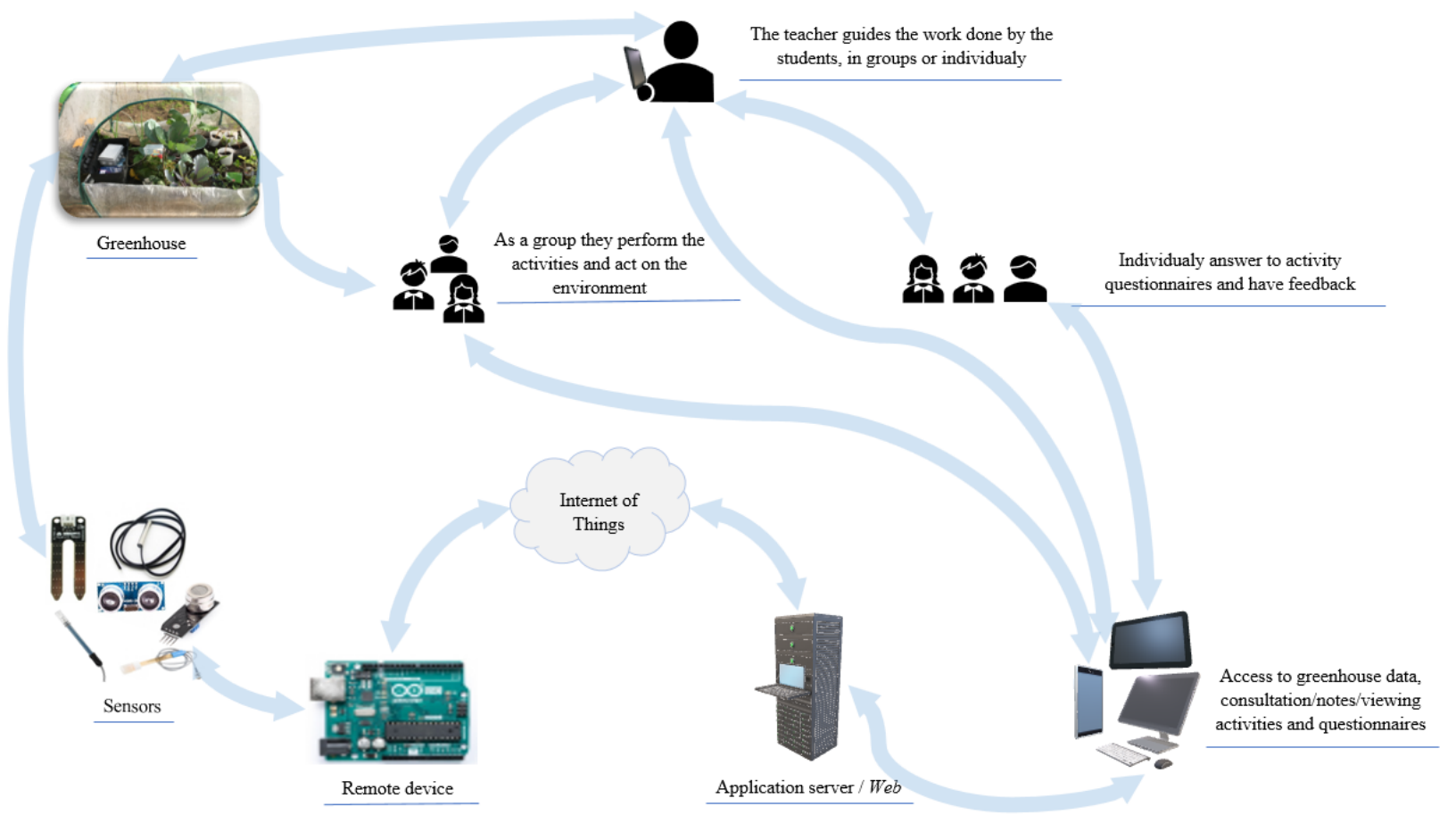

Figure 1. Interaction between the different targets of the SOLL project, prepared by the authors

In this interdisciplinary way, students achieve what is required in the Student Profile when Exit Compulsory Schooling, in which "Areas of Competence add competences understood as complex combinations of knowledge, skills and attitudes that allow effective human action in diverse contexts. They are of diverse nature: cognitive and metacognitive, social and emotional, physical and practical. It is important to emphasize that competences involve knowledge (factual, concetual, procedural and metacognitive), cognitive and psychomotor skills, attitudes associated with social and organizational skills, and ethical values (Martins et al., 2017: 9).

\section{Learning Online Platform - SOLL}

The online learning platform, www.soll.pt built in PHP, an advantageous programming language for building dynamic websites, is supported by a set of technologies that collect and store real data.

Figure 2 shows a map of the SOLL learning platform. To access this learning platform - SOLL, both teachers and students need to do an authentication. For this, they require a user and a password that will be sent by the administrator of the learning platform.

As can be seen from the diagram, students have access only to activities, questionnaires and observations of actual data from the greenhouse. From this platform of learning, students are offered some activities, which comply with the Essential Learning of the respective disciplines and encourages action on the environment. 


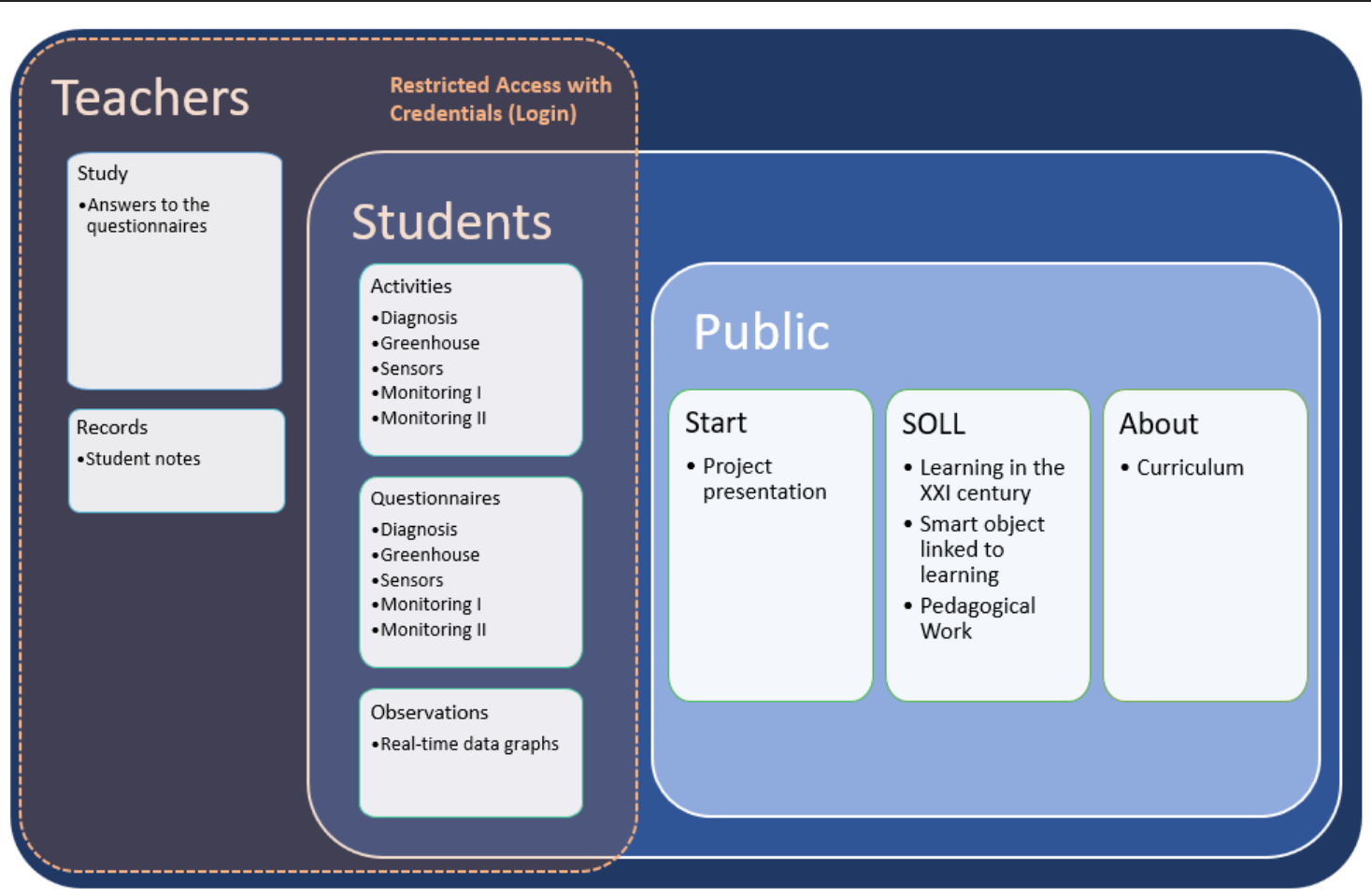

Figure 2. Map of the SOLL learning plataform, elaborated by the authors

Each activity has associated a notepad, useful links for information research, access to tools that work synchronously and asynchronously, for the presentation of the work done and informational documents.

After the activity is carried out, students will be asked to carry out a questionnaire about it and, at the end of it, a feedback on the evaluation and correction of the incorrect answers will. In this way, as you wish, "the assessment is continuous and systematic in the service of learning, and provides the teacher, the student, (...) with information on the development of the work, the quality of the learning done and the ways to improve it" (S. I. de 2018-08-03 Diário da República n.o 149/2018 ...: 3790-(4)) and "the information obtained as a result of the evaluation also allows the revision of the teaching and learning process" (S. I. de 2018-08-03 Diário da República n.o 149/2018 ...: 3790-(4)).

The teachers have access to a management system of student activity on the platform and, the same learning platform, allows teachers to monitor, in real time, the activities carried out by the students through the observation of the notepad, and the answers to the questionnaires. In this way, the teacher has a sense of the students' performance and/or difficulties and can provide a more personalized teaching, since it allows the real time verification of the individual or group work.

To monitor the greenhouse and transmit the data to the platform it was necessary to build a kit based on Arduino technology, several sensors and Wireless module articulated under one interface, Arduino Integrated Development Environment (IDE).

\section{Kit for the Monitoring and Transfer of Greenhouse Data}

This kit allows you to collect actual greenhouse data and send it to the SOLL learning platform that stores it at 15-minute intervals. Figure 3 shows the circuit diagram between the components. 


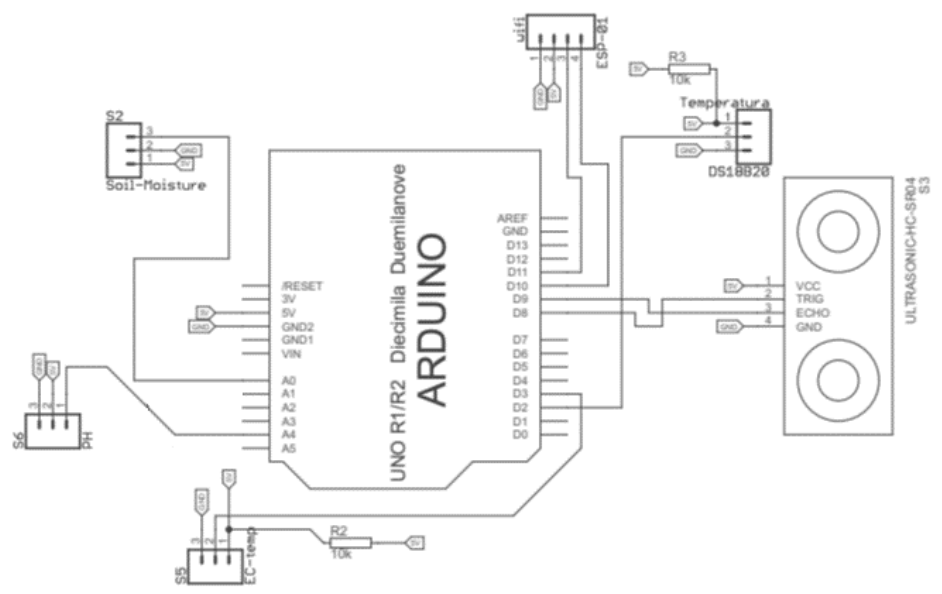

Figure 3. Circuit diagram

\section{Arduino}

Arduino was the interface chosen for this project because it is a platform made up of hardware and software elements very easy to use. This presents itself as a system that can interact with the environment, allowing the development of independent interactive objects or connecting it to a computer and / or a network and sending the data received from the sensors to a platform.

There are several models with several features. However, we used Arduino Uno. It is the latest in a series of Arduino USB cards and the reference model for the Arduino platform.

The Arduino Integrated Development Environment (IDE), can be used with any Arduino board, is open source and can be obtained at arduino website and runs on Windows, Mac OS X and Linux.

The IDE screen consists of the toolbar where the following functions are present: Verify, checks the code before uploading to the Arduino board; Upload, upload the code contained in the sketch window for the Arduino; New Sketch, creates a new blank sketch, ready to receive code; Open Sketch, presents a list of sketches stored in the sketchbook; Save Sketch, save the code in the sketch window for file and Serial Output, opens a window that displays the serial data sent from Arduino, in the lower right corner you can see the transmission rate, that is, the rate per second in which data changes are sent to / from the card, the default setting is 9,600 baud; Sketch Window, place to insert code, that is, a set of indications that tells the computer what to do; Serial Output Window, indicates some error code or other.

Arduino programming presents itself easy in code writing and uploading to the board and happens in two parts. The first one is setup 0 . It is called when a sketch starts telling Arduino what it needs to know to do what we want. It is executed only once, to initialize variables, by setting the pins mode (Input or Output), start libraries, etc. The second is the loop 0. It tells the Arduino what to do with the input or output and repeats itself consecutively while the board is on, allowing the program to change and respond to those changes. Actively controls an Arduino board. It is necessary to make sure the correct board and port selection in the Tools menu before uploading.

With the interface used, we identify the sensors of our prototype to collect data in real time from the monitoring of the greenhouse. The data collected, will allow students, after analyzing and treating them, to act on the medium / object in the control of the variables, in real time and with constant updating and, in an integrated and interdisciplinary way, reach the Curricular Learning Goals proposed by each discipline.

\section{Sensors}

A sensor is a device that "senses", that is, responds to a physical and/or chemical stimulus and can transform that stimulus into another physical greatness for measurement and/or monitoring. In this way, it allows the analysis of a certain factor of the environment where it is inserted.

There is a wide variety of sensors. These can be divided into:

- analog sensors - the most common, in which, in a range of voltage values, you can assume infinite values;

- digital sensors - use binary logic, with well-defined voltage levels, and can only switch between certain welldefined states.

Table 1 shows the sensors used in the SOLL project kit and some characteristics thereof. 
Table 1. Sensors used in the kit of the SOLL Project

\begin{tabular}{ll}
$\begin{array}{l}\text { Sensor } \\
\begin{array}{l}\text { Waterproof temperature } \\
\text { sensor (EC-temp) }\end{array}\end{array}$ & $\begin{array}{l}\text { Description } \\
\text { encapsulated. }\end{array}$ \\
\hline & $\begin{array}{l}\text { A soil moisture sensor can read the amount of moisture present in the soil surrounding it. } \\
\text { This sensor uses the two probes to pass current through the soil, and then it reads that resistance } \\
\text { to get the moisture level. More water makes the soil conduct electricity more easily (less } \\
\text { resistance), while dry soil conducts electricity poorly (more resistance). }\end{array}$ \\
\hline $\begin{array}{l}\text { Analog Electrical } \\
\text { Conductivity, with } \\
\text { temperature sensor }\end{array}$ & $\begin{array}{l}\text { Analog electrical conductivity meter V2 is specially used to measure the electrical conductivity } \\
\text { of aqueous solution, and then to evaluate the water quality, which is often used in water culture, } \\
\text { (DS18820) }\end{array}$ \\
\hline & $\begin{array}{l}\text { aquaculture, environmental water detection and other fields. Conductivity is the reciprocal of } \\
\text { the resistance, which is related to the ability of the material to carry the current. }\end{array}$ \\
Analog pH meter & $\begin{array}{l}\text { Here comes an analog pH meter, specially designed for Arduino controllers and has built-in } \\
\text { sith BND convenient and practical connection and features. To use it, just connect the pH sensor } \\
\text { controller. }\end{array}$ \\
\hline Ultrasound (HC-SR04S3) & The ultrasonic distance sensor is a simple way to measure distances up to 4.5 m.
\end{tabular}

\section{Wireless Module ESP8266}

In today's society, communication, transmission and reception of data in real time, with the possibility of acting on the physical world is of real importance. In this sense, we use the Wireless ESP8266 module (ESP-01), with 3.3V operation voltage. It allows you to connect the Arduino to a WiFi network easily, efficiently and at a low price and thus exchange information between the Arduino, sensors or send them to a computer/tablet/smartphone without the need for wires.

\section{Greenhouse}

For the development of this SOLL project we opted for the monitoring of a greenhouse, as shown in Figure 4, because we recognize, like Morgado (Morgado, 2006: 9), that the greenhouse "inserted in the school environment can be a living laboratory that allows the development of several pedagogical activities in education ... linking theory and practice in a contextualized way, aiding in the teaching-learning process "and by taking care of this, the students acquire new values, new ways of thinking and change their attitudes towards caring for life (Cribb, 2010). For Barbosa (2009), the greenhouse favors cooperative work, allows the relationship between students with different aptitudes and tastes, allows the acquisition of new knowledge and values and allows the student to make decisions, learn to listen and obtain information from different sources.

The greenhouse is polypropylene, was built on the PVC wall with anti-UV treatment and with fiber structure painted green. The greenhouse, with a wall thickness of $0.05 \mathrm{~mm}$, is $110 \mathrm{~cm}$ long, $205 \mathrm{~cm}$ wide and $150 \mathrm{~cm}$ high in the center, allowing a planting area of $2.25 \mathrm{~m}^{2}$.
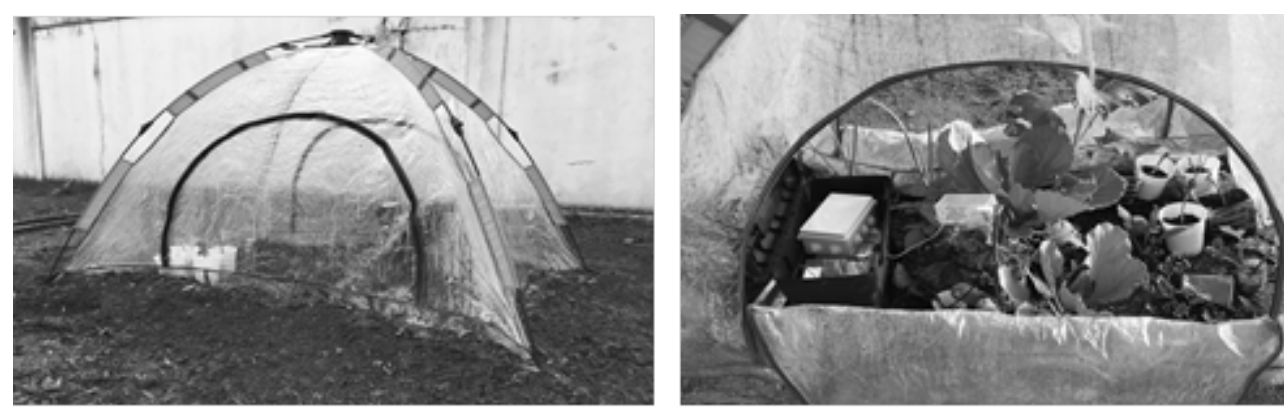

Figure 4. Photographs of the greenhouse used in the SOLL project

From the sliding door, some crops were planted and a box with sensors was placed for monitoring.

From the sensors placed to monitor the greenhouse, real-time data are obtained that, together with open data feeds, will provide results that will be worked out by the students in the accomplishment of some activities that are in the online platform.

\section{Preliminary Results}

The project was applied in 6 classes of the $8^{\text {th }}$ grade, a total of 154 students, $79(51 \%)$ boys and $75(49 \%)$ girls, aged between 12 and 17 years. Figure 5 shows a set of photographs of the performing activities. 

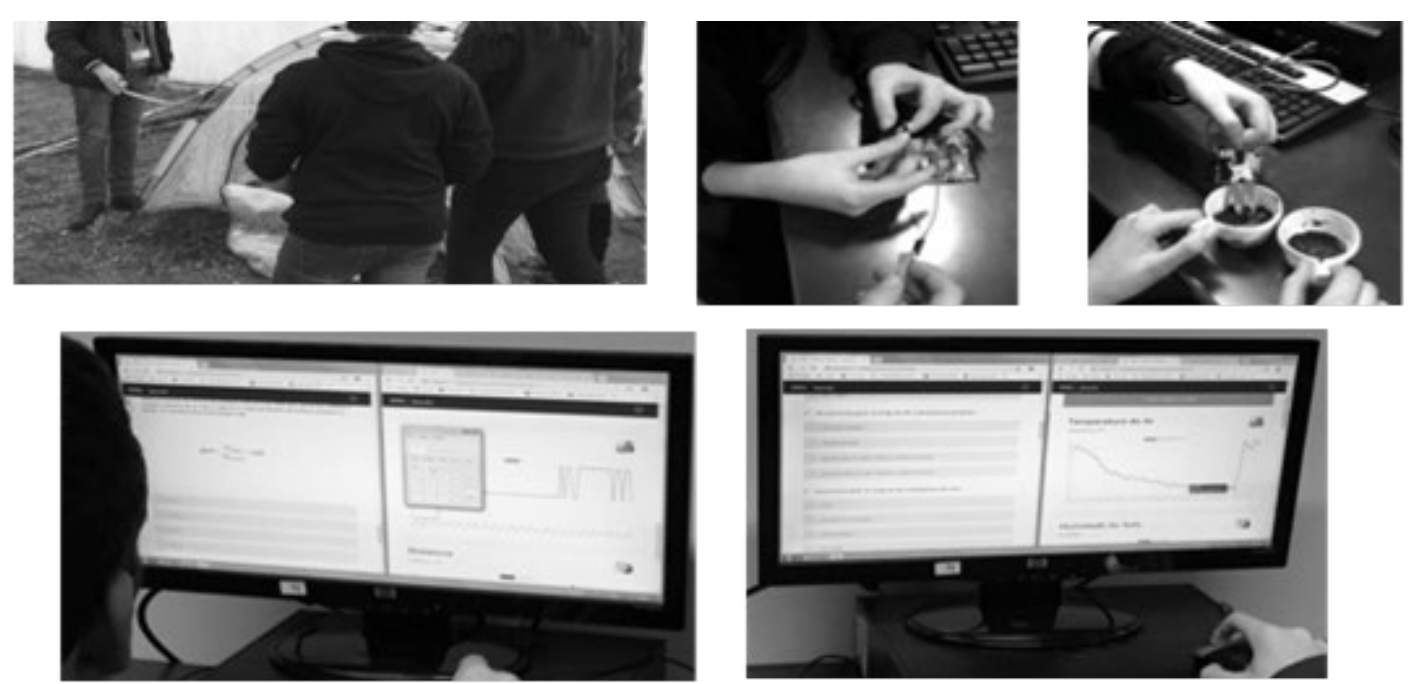

Figure 5. Photographs of activities with students

The activities were carried out in an interdisciplinary way in the disciplines of Physics and Chemistry, Mathematics, Natural Sciences, Geography and ICT.

When the survey was applied, we listed some of the opinions of students and teachers about the work developed in the project SOLL, as shown in Table 2.

Table 2. Some opinions of students and teachers about the SOLL Project

\begin{tabular}{|c|c|}
\hline $8^{\text {th }}$ grade students & \\
\hline $\begin{array}{l}\text { "I think the \& } \\
\text { technologies }\end{array}$ & $\begin{array}{l}\text { "It facilitates the construction of } \\
\text { knowledge as it motivates them more." }\end{array}$ \\
\hline \multirow{2}{*}{$\begin{array}{l}\text { "This activity was a great experience and I really enjoyed this kind of classes and I } \\
\text { think it makes students feel motivated to work with real and not fictional data. I } \\
\text { think it did develop our knowledge and interdisciplinarity content. This activity } \\
\text { could be extended for longer. I really enjoyed this experience." }\end{array}$} & $\begin{array}{l}\text { "It forces them to interpret } \\
\text { critical of the data to be rece }\end{array}$ \\
\hline & \\
\hline SOL & \multirow{2}{*}{$\begin{array}{l}\text { "In this type of activities they get on } \\
\text { with that formative assessment, } \\
\text { because the result is automatic. } \\
\text { Quickly, they can tell: I did not do this } \\
\text { well and why..." }\end{array}$} \\
\hline & \\
\hline $\begin{array}{l}\text { in a lot from the computer world. I hope to have more experiences of these in } \\
\text { ich different contents are approached, in order to expand our knowledge and }\end{array}$ & $\begin{array}{l}\text { "It is perfect for a student interested in } \\
\text { building their learning." }\end{array}$ \\
\hline
\end{tabular}

As we can see, the project SOLL presents itself as a dynamic and innovative educational environment where the learning process is student-centered, providing brain plasticity, discovery of skills and development of softskills.

The promotion of teaching and learning with real and dynamically updated information resources is of real importance for learning, since it allows enriching the learning environment provided to students, fostering interdisciplinarity and the contextualization of learning; contributes to meaningful and interactive learning; stimulates the motivation, allows the perception of learning difficulties; offers students a broader perspective of concepts for a better understanding and acquisition of knowledge and allows the resolution of real problems in the classroom. In this way, the school opens up to the community, fostering lifelong learning, and thus will be valued by all as a true learning community.

\section{CONCLUSION}

Conscious of the explosion of knowledge that took place at the end of the 20th century, the teaching model can not continue to be guided by the transmission of knowledge. This will have to evolve to a model based on the development of competences, in which the student demands a more active role. 
It is presented as a learning environment that can change the school grammar because it allows the classroom to become an "open space" to the community where the physical limitations are not relevant to the interpretation of the surrounding environment. This interactivity that SOLL provides leads students to question the search for information, to explore subjects according to their interests, that is, to become a process much closer to real life and "allows the deep exploration of the process of teaching learning, which awakens all senses and cognitive dimensions, through its non-linear dimension" (Adrião, 2018: 34). This project, using IoT, providing the use of real data, information contextualized with age, interests and geographic location and real challenges from the surrounding environment, allows the students, in an interactive, dynamic and interdisciplinary way, to progress from independent of the teaching materials, adapt to the work pace, repeat what is not clear enough, get feedback from the tests and their progress (Stošić, 2015) and stop being mere users to be authors and producers of multimedia documents (Moreira, 2012), facilitating the construction of their own knowledge.

In this way, the SOLL project could be the ignition to challenge the "teacher of the XXI century to analyze reality and project on it the interests that stimulate students to want to know more, promoting their autonomy, ability to reason, draw conclusions, analyze, synthesize and create new things from those already known" (Adrião, 2018: 132). For a knowledge organization, which is not restricted to the disciplines, requires a different methodology and a collaborative work among all the teachers of the educational team who, according to Fullan and Hargreaves (2001) continues to be the basis of personal and collective renewal.

Thus, the interdisciplinary work allows to explore didactic-pedagogical activities that favor the practical and / or experimental work where the research and analysis is promoted through:

- "the themes or problems addressed from disciplinary perspectives, in an interdisciplinary approach" (S. I. de 2018-08-03 Diário da República n.o 149/2018 ...: 3790-(6));

- "the concepts, facts, relationships, procedures, capacities and competences, in their transversality and disciplinary specificit” (S. I. de 2018-08-03 Diário da República n.o 149/2018 ...: 3790-(6));

- "the textual genres associated with the production and transmission of information and knowledge, present in all disciplines" (S. I. de 2018-08-03 Diário da República n.o 149/2018 ...: 3790-(6)).

It presents a path that is expected to respond to the problem of mass schools and to this new framework of learning community, through the adoption of a different model of learning with exploration of interests and enrichment of educational experiences.

\section{REFERENCES}

Adrião, D. (2018). Um novo paradigma educativo para Portugal no século XXI. Educanology.

Aldowah, I., Ghazal, H., Rehman, S. and Umar, S. (2017). Internet of Things in Higher Education: A Study on Future Learning. J. Phys. Conf. Ser. https://doi.org/10.1088/1742-6596/892/1/012017

Atzori, L., Iera, A. and Morabito, G. (2010). The Internet of Things: A survey. Comput. Networks, 54(15), 27872805. https://doi.org/10.1016/j.comnet.2010.05.010

Barbosa, N. V. S. (2009). A horta escolar dinamizando o currículo da escola. Brasília MEC.

Bruno, S., Schuchter, A. and Junior, L. (2019). Formação docente e uso dos laboratórios de informática na educação básica: divergências entre os contextos do discurso oficial e da prática. In Educação e Tecnologias na Sociedade Digital; Whitebooks.

Comissão Europeia (2012). Comunicação da Comissão ao Parlamento Europeu, ao Conselho, ao Comité Económico e Social Europeu e ao Comité das Regiões, Repensar a Educação - Investir nas Competências para melhores resultados socioeconómicos.

Costa, H. (2014). Inovação Pedagógica: A tecnologia ao serviço da educação. Chiado Ed.

Cribb, S. L. S. P. (2010). Contribuições Da Educação Ambiental E Horta Escolar Na Promoção De Melhorias Ao Ensino, À Saúde E Ao Ambiente. Rev. Eletrônica do Mestr. Prof. em Ensino Ciências da Saúde e do Ambient., 3(1), 4260. https://doi.org/10.22409/resa2010.v3i1.a21103

Fullan, A. and Hargreaves, M. (2001). Por que é que vale a pena lutar?. Porto Ed.

Gubbi, M., Buyya, J., Marusic, R. and Palaniswami, S. (2013). Internet of Things (IoT): A vision, architectural elements, and future directions. Futur. Gener. Comput. Syst., 29(7), 1645-1660. https://doi.org/10.1016/j.future. 2013.01.010

Johnson, L., Adams Becker, S., Estrada, V., and Freeman, A. (2015). Horizon Report: 2015 Higher Education Edition.

Kranenburg, R., et al. (2016). The Internet of Things. Pap. 1st Belin Symp. Internet Soc. Oct. 25-27.

Magalhães, A., Andrade, A. and Alves, J. (2019). SOLL: Smart Objects Linked to Learning - Educational platform with the Internet of Thingsitle. In 2019, 14 a Conferencia Ibérica Sist. e Tecnol. Informação (CISTI), IEEE. https://doi.org/10.23919/CISTI.2019.8760921 
Martins, S., Gomes, G., Brocardo, C., Pedroso, J., Carrillo, J., Silva, J., Encarnação, L., Horta, M., Calçada, M., Nery, M. and Rodrigues, R. (2017). Perfil dos Alunos à Saída da Escolaridade Obrigatória. Ministério da Educ. Direção Geral da Educ.

Moreira, J. A. (2012). Novos cenários e modelos de aprendizagens construtivistas em plataformas digitais. In Educação online - Pedagogia e a prendizagem em plataformas digitais, 27-44.

Morgado, J. (2006). A Horta Escolar na Educação Ambientar e Alimentar: experiências do projeto horta viva nas escolas municipais de Florianópolis. Cent. Ciências Agrárias. Univ. Fed. St. Catarina, Florianópolis.

Morgado, L. (2015). INGRESS: Potencialidades Pedagógicas de um jogo Georreferenciado de Realidade Alternativa em Rede. In Inovação e Formação na Sociedade Digital. Ambientes Virtuais, Tecnologias e Serious Games.

O’Brien, H. M. (2016). The Internet of Things. J. Internet Law, 19(12), 1-20. https:/ /doi.org/10.1007/978-1-48422108-2_1

Osborne, J. and Dillon, J. (2008). Science Education in Europe: Critical Reflexions. London Nuff. Found.

Patrício, M. (2019). Educação e formação em TIC intergeracional. In Educação e Tecnologias na Sociedade Digital; Whitebooks.

Reid-Martinez, L. D. and Grooms, K. (2018). Online Learning Propelled by Constructivism. Encycl. Inf. Sci. Technol. (4th Ed., pp. 2588-2598). IGI Glob. https:// doi.org/10.4018/978-1-5225-2255-3.ch226

S. I. de 2018-08-03 Diário da República n.o 149/2018, 1o Suplemento, "Decreto-Lei n.o 55/2018, de 6 de julho."

Singer, T. (2012). Tudo conectado: conceitos e representações da internet das coisas. Simpósio em Tecnol. Digit. e Sociabilidade - Práticas Interacionais em Rede.

Slimp, R. and Bartels, M. (2019). How the Internet of Things is Changing our Colleges, our Classroom, and our Students. Foreword by Fred Lokken. Br. Libr. Publ. Inf.

Souza, L. (2010). Estratégias de aprendizagem e fatores motivacionais relacionados. Educ. rev., Curitiba, (36). https://doi.org/10.1590/S0104-40602010000100008

Stošić, L. (2015). The Importance of Educational Tecnology in Teaching. Int. J. Cogn. Res. Sci. Eng. Educ., 3(1).

Sultan, A., Woods, W. and Koo, P. (2011). A constructivist approach for digital learning: Malaysian schools case study. Educ. Technol. Soc., 14(4), 149-163.

Xia, F., Yang, L. T., Wang, L. and Vinel, A. (2012). Internet of Things. Int. J. Comun. Syst., $25(9), 1101-1102$. https://doi.org/10.1002/dac.2417 